\title{
İstanbul'daki Hemşehri Dernekleri Toplum Afet Bilinci Geliştirmede Etkin Rol Üstlenebilir mi?
}

\author{
Gül YÜCEL ${ }^{1}$ ve Didem GÜRBÜZ ${ }^{2}$
}

Öz

Çalışmada toplum afet bilinci geliştirmede mevcut sivil toplum kuruluşları altyapısının kullanılabilirliği tartışımıştır. Bu kapsamda sivil toplum kuruluşu olarak "Hemşehri Dernekleri"nin kentte kurduğu sosyal dayanışma ağlarının temel afet bilincinin yaygınlaştırılmasında kullanılabilirliği İstanbul sınılııı̆ında incelenmiştir. Hemşehri dernekleri ülke genelinde ve daha çok göç alan büyük kentlerde yaygın sosyal ağı ile geleneksel dayanışma kültürünün kentlerdeki uzantısı olarak karşımıza çıkmaktadır. İstanbul'un araştırma alanı olarak seçiminde hemşehri derneklerinin yoğun olarak faaliyet göstermesi, deprem tehlikesi altında olması ve afet riskleri taşıması ekten olmuştur. Çalışmada nitel araştırma yöntemlerinden görüşme tekniği yoluyla veri toplanmıştır. İstanbul'da hâlihazırda 135 federasyon altında toplanmış 6304 hemşehri derneği bulunmaktadır. Hemşehri derneklerinin yapısı ve sayıca fazla oluşu, araştırmada kullanılacak araçların şekillenmesinde etkili olmuş, araştırmanın hemşehri derneklerinin bağlı oldukları federasyonlar yoluyla yapılmasını beraberinde getirmiştir. Bu doğrultuda hemşehri derneklerinin bağlı olduğu federasyonlarla iletişim kurulmuş ve görüşmeyi kabul eden altı federasyonla ayrıntılı görüşme yapılmıştır. Yapılan araştırma sonuçları, konuyla ilgili istekli olunmakla birlikte ön çalışma ve hazırlıkların gerekliliği ortaya çıkmaktadır.

ANAHTAR KELímELER: Afet, afet bilinci, sivil toplum kuruluşu, hemşehri derneği, İstanbul

\section{Can Fellow Countryman Associations in Istanbul Take Active Role in Disaster Awareness?}

\begin{abstract}
In this study, usefulness of existing network of non-governmental organizations such as fellow countryman association for enhancing disaster awareness is discussed. Fellow countryman associations appear as the extension of traditional solidarity culture with widespread social network throughout the country and in big cities receiving more immigration. Due to the being under the threat of earthquake and capacity of social and educational activities of fellow countryman associations, Istanbul is selected for case study area. Data is collected through interview technique, one of the qualitative research methods. There are currently 6304 fellow countryman associations gathered under the135 federations in Istanbul. The structure and large number of fellow countryman associations are effective for determining the tools to be used in the research and bring the research through the federations of fellow countryman associations. In this regard, communication is established
\end{abstract}

\footnotetext{
${ }^{1}$ Mimarlık Bölümü, İstanbul Gelişim Üniversitesi, İstanbul

${ }^{2}$ International Federation of Red Cross and Red Crescent Societies (IFRC), Proje Sorumlusu, Ankara

*ilgili yazar / Corresponding author: gyucel@gelisim.edu.tr 
with the federations which fellow countryman associations are affiliated and a detailed interview is conducted with the six federations that accepted the meeting. According to research result, there is needed to preliminary studies and preparations despite of their willing.

KEYWORDS: Disaster, disaster awareness, non-governmental organization, fellow countryman association, Istanbul

\section{GiRiş}

Toplum temelli afet riski azaltma çalışmaları son yıllarda afet yönetimi konusunda en çok tartışılan alanlardan biridir. Genel kanı, herhangi bir afet durumunda devlet yetkilileri veya ulusal otoritelerin bu durumun üstesinden geleceği yönündedir. Ancak gerçekte ve her afette olduğu gibi afet riski altındaki topluluklar hem en yüksek etki altında kalacak, hem de en çok zarar görecek topluluklar olmaktadır (Shaw, 2012). Toplum temelli çalışmalar; yönetim şeması yukardan aşağı olarak örgütlenen, bürokratik aşamaları çok olan ve lojistik destek sıkıntılarının yaşandığı afet riski azaltma çalışmaları yerine, bölgesel (yerel) çalışmalara yönelmektedir. Bu nedenle toplum temelli afet risk azaltma çalışmaları, afet risklerini azaltmak ve yönetmek için önemli olmaktadır. Afet yönetimi, sadece teknik ve afet sonrası mühendislik alanında çalışılması gereken bir konu değil, aynı zamanda disiplinler arası ve yerel toplulukların sosyoekonomik aktivitelerini de kapsayan bir konu olarak ele alınmalıdır (Maskrey, 1989). Afet öncesi hazırlık ve afet sonrası iyileşme süreçlerinde en iyi ve hızı sonucu almak için yalnızca mühendislik yönetimi ve teknik bilginin yeterli olamayacağı anlaşılmış, toplulukların eğitiminde sosyal sermayeye vurgu yapılmıştır. Bu konuda yapılan bir çalışma sosyal sermayenin ve grup liderliğinin yüksek olduğu topluluklarda (gelir düzeyi düşük olsa bile) afet sonrası iyileşme sürecinin diğer topluluklara oranla hızlı olduğunu ortaya koymaktadır (Nakagawa \& Shaw, 2004). Sosyal sermaye genel anlamda, topluluklarda kişilerin birbirine olan güveni, bireyler ve gruplar arasındaki sosyal bağlar, sosyal hayata katılım ve sosyal normlarla (borç, yükümlülük veya gönüllülük gibi) ölçülmektedir. Afet sonrası iyileşme sürecinde toplumların intiyacı olan yardımlaşma ve ortak kararlar vermek gibi eylemler, güven ortamının ve sosyal bağların yüksek olduğu ortamlarda daha kolay ortaya çıkmaktadır. Sosyal sermayenin yüksek olduğu topluluklarda bu sürecin daha hızlı olacağını söylemek mümkündür. Afet bilinci geliştirmede, büyük kentlerde yaygın sosyal ağı ile sosyal sermeyesi yüksek sivil toplum kuruluşu (STK) sayılabilir hemşehri derneklerinin de rol üstlenebileceği düşünülebilir. Büyük kentlerde "hemşehri" derneklerinin hem üyeleri arasındaki sosyal bağların kuvvetli olduğu, hem de yerel veya merkezi yönetim alanına dâhil olup siyasal süreçleri etkiledikleri bilinmektedir (Özdemir, 2013). Dahası bu derneklerin büyük şehirlerde ilçe veya mahalle ölçeğinde sahip oldukları yardımlaşma ve dayanışma bağlarıyla afet sonrası iyileşme sürecini hızlandırabileceği öngörülmektedir. Afet bilinci eğitimlerinin bu dernekler yoluyla yaygınlaştırıması, birbirleri arasındaki güven bağları yüksek olan bu topluluklarda katılımı arttırıcı etkide bulunabilir. Yapılan ön araştırmalarda bu derneklerin afet eğitimi için kullanılması yönünde kapsamlı bir çalışmaya rastlanmamıştır. Bu durum, bu alanın çalışılması gerektiğini ortaya koymaktadır.

Uluslararası, ulusal ve yerel seviyelerde afet önleyici ve risk azaltıcı eylemlerin vurgulandığı "Sendai Risk Azaltma Çevresi 2015-2030"da, toplumların afet karşısındaki dirençlerini geliştirmede ilgili kurum, kuruluş ve sivil toplum örgütlerine önemli görevler düştüğü belirtilmektedir (UNISDR, 2015). Aynı zamanda Dünya, bölge, ülke ve yerel ölçeklerde afet riskini anlama, afet risk yönetimini güçlendirme, etkin hazırlık ve iyileştirme çalışmaları için hazırlıklar kapsamında afet önleme kültürünün ve afet bilincinin geliştirilmesi, bu yönde merkezlerin geliştirilmesi, teşviklerin sağlanması benzeri konular ön plana çıkarılmaktadır (UNISDR, 2015). Sendai Risk Azaltma Çerçevesi 2015-2030'da yer alan dört öncelikten ilki 
olan afet riskini anlama; dünya ve bölgesel ölçekte toplumsal farkındalık geliştirme, afet önleme kültürünü geliştirmede çeşitli kampanyaların sürdürülmesi öngörülmektedir (UNISDR, 2015). Aynı planda yer alan, afet risk yönetimini güçlendirmeyi içeren ikinci öncelikte ise ulusal ve bölgesel ölçekte; afet bilincinin artması ve eğitimin teşviki, mali teşvik içerebilir afet riskinin şeffafığının sağlanmasına yönelik mekanizma ve girişimlerin güçlendirilmesi, afet farkındalık kampanyalarının koordinasyonu ön planda tutulmaktadır. Etkili hazırlık ve iyileştirmeler için afete hazırlığın geliştirilmesini içeren dördüncü öncelikte ise ulusal ve bölgesel ölçekte afet bilincini geliştirme ve intiyaçların karşılanmasına yönelik merkezlerin geliştirilmesi ön plana çıkmaktadır (UNISDR, 2015). Uluslararası düzeydeki bu çerçeve planda da belirtildiği gibi mühendislik önlemlerinin yanında toplumun bilinçlendirilmesi, konunun sürekli gündemde canlı tutularak güncel bilgi akışının kitlelere yaygınlaştırılması ve sosyal yapının güçlendirilmesi önemli ve öncelikli çalışma alanlarıdır.

\section{TÜRKIYE AFET BiLINCI GELIŞTiRME ÇALIŞMALARI}

Türkiye'de toplum afet bilincinin gelişimi, afet kültürünün toplumsal hayatın içinde yer alması ve bunun sistematik bir yaklaşımla ele alınması belirgin şekilde 1999 Marmara depremi sonrasına rastlar. Hazırlanan İstanbul Master Planı (IBB, 2003), Afet Önleme /Azaltma Temel Plan (IBB-JICA, 2002) çalışmaları afet kapsamında ve deprem özelinde önemli analiz ve değerlendirmeleri içermektedir. İstanbul Deprem Master Planı (2003), eğitim başlığı altında mevcut durumu da ele alarak bu yönde geliştirilecek projeleri ayrıntılı olarak ortaya koymuştur. Raporda doğrudan sunulan uygulamalı halk eğitimi ve görsel medya yoluyla yaygın halk eğitim modeli önerilmiştir (IBB, 2003). Öncelikle eğitim programında güvenirlik ve inandırıcılığın kesin olarak önemli olduğu vurgulanmaktadır. Duygu, düşünce, tutum ve beklenti bütününe hitap edebilmesi, depremin başa çıkılabilecek bir doğa olayı olduğu konusuna odaklanılması, yeterlilik-yapabilirlik bilinci oluşturmak, depreme hazır olmanın insan hakkı olduğunu düşündürmek, halk ve idare arasında bir dayanışma etiği oluşturmak, halkın değerlerine ve yargılarına saygılı tutum, program ve eğitim etkinliğinin sınanması gerekliliği belirtilmektedir. Önerilen uygulamalı halk eğitimi programında yerel kültür ve yapılanmaya uygun eğitim programının önemi vurgulanmıştır. Rapordaki diğer öneri model ise görsel medyanın toplum eğitiminde kullanılmasıdır. Televizyon için hazırlanacak eğitici belgesel seri olarak önerilen eğitim modeli önerisinde deprem riski ve risk azaltma için yapılabileceklerin sıralanması önerilmektedir. Halk eğitiminde kolay erişilebilir okul, halk eğitim merkezi gibi yerler önerilmektedir. Afet kapsamında halk eğitiminde salt mevcut merkezlerin kullanılması yerine toplumda var olan sivil toplum örgütlenmesinden de yararlanılması bu sürecin hızlandırılmasına katkı sağlayabileceği düşünülmektedir.

Afet bilinci geliştirme eğitim çalışmalarından ilk önemli ve kapsamlı olanı Boğaziçi Üniversitesi Kandili Rasathanesi Deprem Araştırma Dairesinin başlattığı çalışmalardır (KRDAE, 2017). Marmara depremi sonrası geliştirilen Afete Hazırlık Eğitimi Projesi (AHEP) kapsamında farklı içeriklerde eğitim programları ve yayınlar hazırlanmıştır. Üç bini aşan öğretmene verilen eğitmen eğitimleri ile (2001-2002) bir milyona yaklaşan öğrenci ve veliye eğitim verilmesi sağlanmıştır. Aynı şekilde deprem simülasyon tırı ile Türkiye'nin her bölgesine ulaşılarak deprem ve afet konusunda bilgilendirme sağlanmaktadır. Hâlihazırda bireysel ve kurumsal eğitim verme faaliyeti sürdürülmektedir.

Son dönemde yapılmış önemli projelerden biri AFAD'ın Afet Bilinci Geliştirme Projesidir (AFAD, 2017). Söz konusu proje kapsamında gerçekleşen eğitimlerle Türkiye genelinde beş milyonu aşan kişiye ulaşıldığı belirtilmektedir (AFAD, 2017). Bugün için ise bu sayının 11 milyonu aştığı görülmektedir (URL-1). AFAD ilçe örgütleriyle birlikte yürütülen bu çalışmalarla, merkezlerde toplanan katılımcılara afet bilinci yaygınlaştırma seminerleri verilmektedir. 
Özellikle 1999 Marmara Depremi'nin ardından takip eden dönemde örgün ve yaygın eğitim programlarında afet ve deprem konusuna daha çok yer verildiği gözlenmektedir. Fiziksel yapılı çevre ile ilgili mühendislik ve mimarlık eğitimlerinde deprem ve afet faktörü daha belirgin bir biçimde müfredata dâhil edilmiştir. Bu konuda Ulusal Deprem Stratejisi Eylem Planı 2012-2023'de "Deprem Güvenli Şehirler ve Yapılaşma" ana eyleminde ilgili eğitim alanlarında müfredatın bu yönde güçlendirilmesi (UDSEP 2012/2023, Eylem B.1.7.1) yer almaktadır (AFAD, 2013). Diğer taraftan Milli Eğitim Bakanlığı'nca (MEB) Yaşam Boyu Öğrenme Programlarına afet bilinci geliştirme modülleri eklenmiş ve halk eğitimi kapsamında yaygınlaştırılması hedeflenmiştir (MEB, 2011).

İstanbul Valiliği tarafından "Güvenli Yaşam" sloganı ile yürütülen kampanyalarla, afet bilinci geliştirme konusunda kapsamlı seminer, konferans, eğitim benzeri çalışmalar gerçekleştirilmiştir (IPKB, 2017). Afet teması ile doğrudan ilişkili Arama Kurtarma Derneği AKUT ve benzeri sivil toplum kuruluşları, belediyeler, gönüllü gruplar da bu yönde çeşitli bilinçlendirme etkinlikleri gerçekleştirmiştir. AKUT(2015) afet ve deprem bilinçlendirme seminerleri ile yüz bin kişinin üzerinde kişiye ulaşmıştır (AKUT, 2015). Kadıköy Belediyesi tarafından afet konusunda halkı bilinçlendirmek, afet sırasında yapılması gerekenleri, afet sonrası alınabilecek önlemleri uygulamalı bir şekilde anlatabilme amaçlı "Afet Eğitim ve Bilinçlendirme Parkı" açılmıştır (URL-2). Esenler Belediyesi Arama Kurtarma Ekibi- ESKAT (2016) toplum afet bilinci geliştirme yönünde birçok eğitim vermeye devam etmektedir (URL3). Kartal Belediyesi ve AKUT Vakfı ortaklığında geliştirilen toplumun afet konusunda eğitim alabileceği "Toplum Afet Bilinçlendirme Merkezi" kurulmuştur. (URL-4). Avcılar Belediye'si tarafından afete hazırlık kapsamında 2015'de geliştirilen Avcılar Belediyesi Afet Gönüllüleri ABAG projesi $(A B, 2018)$ kapsamında aylık toplantılar gerçekleştirilmekte ve ilçede yaşayanlar afet konusunda bilgilenmekte, sorularına yanıt bulmaktadır. Aynı proje kapsamında ilçedeki hemşehri dernek merkezlerinde de afet konulu toplantılar gerçekleştirilmiş, toplantıya belediye başkanı da katılmıştır.

Gerçekleştirilen ve sürdürülen çalışmalar çok farklı noktalarda geliştirilmiş olsa da toplum afet bilinci geliştirme üzerindeki etkisi önemlidir. Bu kapsamda afet bilinci geliştirmeye yönelik eğitimlerin yaygınlaştırılması hayati önem taşımaktadır. Günün koşullarına paralel geliştirilmiş yeni modellerin de bu çalışmalar içinde yer alması toplum afet bilinci geliştirilmesi hedefine olumlu katkı sağlayabilir. Toplumun heterojen yapısı ve yerleşimlerin farklılıklar içermesi, eğitimlerin çok farklı araç ve yöntemlerle yaygınlaştırılması intiyacını da ortaya koymaktadır. Fiziksel ve diğer güçlükler içindeki bireylerin bu konudaki bilinçlenme eğitimleri için daha farklı yer, yöntem ve araç seçimi etkin sonuç elde edilmesine katkı sağlayabilir. Bu tür eğitimin toplumun her kesimini kapsayıcı yapıda olması, yaygınlaştırmada etken faktör sayılmaktadır. Yaş, cinsiyet, eğitim, kültürel yapı benzeri sosyodemografik ve sosyokültürel parametreler afet bilinci geliştirme faaliyetleriyle ilgili araç ve yöntem seçiminde önemli rol oynamaktadır.

Bilimsel çalışmalar, yenilikçi uygulamalar ve değişen fiziksel, sosyal, ekonomik ve çevresel bileşenler afet bilincinin geliştirilmesi sürecinin de sürekli yenilenen yapıda olmasını beraberinde getirmektedir. Eğitimin şekli, yeri ve araçları değişkenlik gösterebilmektedir. Enformel ve yerinde eğitimler de afet bilinçlendirmede daha etkili sonuçlar oluşturabilir. Bu nedenle kamusal, kurumsal yaklaşımlarla birlikte sivil toplum kuruluşlarının bu sürecin içinde yer alması, sosyal sermayenin afet bilinci geliştirmede katkı sağlayıcı düşünülebilir. Sivil toplum kuruluşları içinde doğrudan afetle ilişkili olanlar dışında dayanışma odaklı ve yaygın sosyal ağı bulunan hemşehri derneklerinin de değerlendirilmesi bir araştırma alanıdır. Aynı zamanda küresel etkiler, afet için ülke sınırlılığını da etkilemekte ve bu konudaki anlayışı değiştirmektedir. Bu konuda geliştirilen eğitim modelleri dışında, küçük ölçekte ve bölgesel 
olarak kendine özgü yöntemler daha etkin olabilir. Her ülke özelinde genel çerçevenin içinde kalacak biçimde, farklı araç ve yöntemlerin geliştirilebilmesi önemli araştırma alanıdır.

\section{AFET BILLINCI GELIŞTIRME VE SIVIL TOPLUM KURULUŞLARI}

Afet risk azaltma çalışmaları kapsamında farklı alanlarda gerçekleştirilen önlem, müdahale, düzenleme, iyileştirme, güçlendirme benzeri çalışmalarla birlikte, afete dirençli toplum yönünde halkın bilinçlendirilmesi çalışmaları da önemli konulardan biridir. Temel afet bilinci eğitimi, bireylerin afetin ilk 72 saatine hazırlıklı olması, afet kültürünü kazandırma, yaşadıkları mekânlarda alabilecekleri temel önlemler, doğru davranış biçimleri benzeri bilgileri içermektedir (MEB, 2011). Gerek kamu ve gerekse sivil toplum kuruluşları afete dirençli toplum yönünde afetin her evresi için çeşitli görevler üstlenmektedir. Devam eden çalışmalarla birlikte nüfusa paralel bilinçlendirme eğitimlerinin geliştirilmesi ve bu konuda verimli ve hızlı ilave yöntemlerin kullanılması afete hazırlık açısından güçlendirici katkı sağlayabilecektir. Bu nedenle bu türden çalışmaların yaygınlaştırılmasında etkin araçların geliştirilmesi önemli bir çalışma alanıdır.

Sivil Toplum Kuruluşları (STK) afet öncesi ve sonrasında devlet kurumlarından sonra akla ilk gelen yardımlaşma ve dayanışma kurumlarıdır. Dünyada ve Türkiye'de pek çok örnekte olduğu gibi STK'lar afet öncesi ve sonrasında kurtarma, koordinasyon ve yardım faaliyetlerinde etkin roller üstlenebilmektedir. Afetlere hazırlıkta; özellikle yerel topluluklara etkili bir şekilde uygulandığında, kişiler karşılaşacakları riskleri öğrendiklerinde bir sonraki afette karşı koyabilecekleri stratejiler ve acil durum planları geliştirebilmektedir. Bu nedenle eğitim, afet karşısında önlem alabilmek için önemli ilk adımdır. Eğitilmiş bir topluluk, acil durumlarda doğru davranışlar sergileyebilir, doğru stratejiler geliştirebilir, aynı zamanda afet sonrası iyileşme sürecini de hızlandırabilir. Afetler konusunda toplumsal farkındalığı arttırmak ve afet risklerini azaltmak konulu eğitimlerde STK'lar önemli bir konumdadır. Afet öncesinde yapılacak toplumsal farkındalık eğitimleri, afete hazırlık ve afet etkilerini azaltma eğitimleri vermek gibi sorumluklar üstlenebilmektedir.

Uluslararası Kızılhaç Federasyonu IFRC (2011) afet risk azaltma kapsamında halkın bilinçlendirilmesi veya başka bir deyişle halkın eğitimine yönelik, kampanyaların hazırlanması, katıımcı öğrenme, enformel eğitim ve okul temelli formel yaklaşımlar olarak dört temel yaklaşım öngörmektedir (IFRC, 2011). Hazırlanacak kampanyalar standart mesajlarla geniş ölçekte ve düzenli biçimde bir etki sağlamaktadır. Çözüme katılımcı yaklaşım; halkın kendi fikirleriyle çözümün parçası olması ve afet risk azaltmada problem çözme ve keşfetmeyi kapsamaktadır. Enformel eğitim ise kısa anlar ve buluşmalar ile insanların güvenlik ve esnekliğini artırmak üzerine düşünmeyi teşvik etmektir. Enformel eğitim, okulda ve toplum içinde gerçekleşebilen, zaman, katılımcı ve düzenlemeler açısından en esnek olanıdır (IFRC, 2011). Bu eğitim, evde, okulda veya iş ortamında, televizyon, radyo ve internet aracılığı ile bir iki dakikadan bir iki günlük periyotta planlı veya spontane geliştirilebilir kapsamda olabilmektedir. Okul temelli formel yaklaşım ise okul kapsamında afet yönetimi ve afet risk azaltmayı kapsamaktadır.

\subsection{Sosyal ağ olarak hemşehri dernekleri}

Hemşehri dernekleri Türkiye'de 1950'lerden sonra köyden kente yaşanan göçün bir parçası olarak kentlerde kurulmuş ve zaman zaman farklı işlevler kazanmış sivil toplum kuruluşlarıdır. Hemşehri, aynı köy, ilçe veya şehirden olan kişilerin birbirleri için kullandıkları tanımlamadır. "Memleketli" de aynı tanımın diğer karşılığıdır. Hemşehrilik sözcüğü memleketleri aynı coğrafi yer olan veya aynı coğrafi yere ait olma hissini taşıyan kişiler arası ilişkileri; onlar arasındaki bağları ve bu bağlardan doğan çeşitli kimlikleri tanımlar (Altay, 2009: 84). Hemşehriler, kentte tutunabilme, iş ve konut bulabilme, kültürel kimliklerini koruma, kamuoyunu etkileyebilme ve baskı gücü oluşturabilme gibi amaçlarla birbirleriyle 
dayanışma içerisindedirler (Koçak ve Terzi, 2014: 142). Kurtoğlu (2005), hemşehrilik ilişkilerinin aynı çıkara sahip olmaktan ziyade aynı kültüre sahip olmak ve aynı coğrafi yerle bağ kurmak anlamında kullanır, grup yerine cemaatimsi/ cemaat kelimesinin daha doğru bir karşılık olduğunu savunur.

Hersant ve Toumarkine (2005) hemşehri derneklerini bir buluşma noktası olarak değil, daha çok politik ve sosyal ağların oluştuğu bir yer olarak tanımlar. Hemşehri dernekleri; göç araştırmalarının yanı sıra, dernek yapılanmalarının merkezi seçimlerle ve siyasetle olan ilişkisi üzerine akademik çalışmalara konu olmuştur (Hersant ve Toumarkine, 2005; Kurtoğlu, 2005). Daha çok kültürel ortaklıkla bağdaştırılan bu örgütlerin siyasal alanda da ortaklık kurabildiğini ve etkili olduğu görülmektedir. Hersant ve Toumarkine (2005) hemşehri derneklerinin bölgesel ve ulusal siyasi temsiliyetlerini araştırdıkları makalesinde "bölgesel düzeyde" politik temsil olmadığından, köy ve şehir arasında aracı kurumlar aracılığıyla siyasi temsili olduğunu belirtirler. Hemşehri dernekleri, büyük şehirlerde yerel ve merkezi güçler arasında bağ kuran bir araç olarak görülebilir. Yerelin temsilinin büyükşehirlerde ve seçimlerde söz sahibi olmasının bir yolu da hemşehri derneklerinin aktif olmasına bağlıdır denebilir. Bu durumda, hemşehri dernekleri, insanların ulusal ve merkezi yönetime entegrasyonuna yardımcı olmaktadır. Merkezi yönetime entegrasyon noktasında siyasi organizasyonların etkinlik alanını genişletmesi ve enformel insan ve kaynak seferberliği göz önünde bulundurulurken, insan ve kaynak seferberliğinin afet risk azaltma çalışmaları kapsamında ne oranda etkin olduğu önemli bir sorudur. Bu kapsamda afetle ilişkili hemşehri derneklerinin konuya bakış açıları ve mevcut yapılarının ortaya konması önemli olacaktır. Literatüre göre hemşehri derneklerinin afetle ilgili yaklaşımlarının olumlu yönde olduğu söylemek mümkündür (Gürbüz ve Yücel, 2017).

Toplum afet bilinçlendirme eğitim platformu olarak farklı ve etkin alternatif olarak düşünüldüğünde araştırmanın temel soruları;

1-Afet bilinci geliştirmede mevcut sosyal ağlardan yararlanılabilir mi?

2-Yaygın örgütlenmiş yapısıyla hemşehri derneklerinin hâlihazırdaki sosyal ağı afet bilinci geliştirmede kullanılabilir mi?

3- Bu yapıların kullanılabilirliğini geliştirmek için etkin araçlar nelerdir?

\section{MATERYAL VE YÖNTEM}

Araştırma İstanbul merkezli hemşehri dernekleri sınırlıı̆ında gerçekleştirilmiştir. Hemşeri dernekleri köylerden kente göçle de bağlantılı olarak daha çok İstanbul, Ankara, İzmir gibi büyük şehirlerde faaliyetlerini sürdürmektedir. Afet bilincinin geliştirilmesi afet riski altındaki yerleşimler için öncelikli konulardan biridir. Bu yönde yapılacak çalışmalar afete karşı duyarlılığı artıracak ve her ölçekte alınacak önlemler risk azaltma çalışmalarında geniş toplulukları olumlu yönde etkileyecektir. Marmara bölgesi ve özellikle İstanbul, deprem tehlikesi altında ve afet riski taşımaktadır. Araştırma alanı olarak İstanbul'un seçimi, hemşehri derneklerinin sayıca çokluğu, ve yoğun olarak faaliyet göstermeleri, ayrıca deprem tehlikesi altında olma durumu gözalınarak belirlenmiştir. İstanbul ili sınırları dâhilinde hâlihazırda 6304 hemşehri derneği ve bağlı oldukları 135 federasyon bulunmaktadır. Hemşehri derneklerinin İstanbul ili sınırları dâhilinde bulundukları ilçelere göre dağılımı farklılık göstermektedir. İstanbul'da faal 6304 hemşehri derneği; Adalar (3), Çatalca (15) ve Şile(23) gibi ilçelerde en az sayıda faaliyet gösterirken, Bağcılar (447), Ümraniye (368), Küçükçekmece (328), Esenler (316), Bahçelievler (293), Kâğıthane (298) gibi ilçelerde yoğun olarak faaliyet göstermektedir (DERBíS, 2017). Genel olarak bakıldığında İstanbul, bu potansiyeli değerlendirme açısından önemli bir çalışma alanı olarak karşımıza çıkmaktadır. 
Hemşehri derneklerinin yapısı ve sayıca fazla oluşu, araştırmada kullanılacak araçların şekillenmesinde etkili olmuş, araştırmanın hemşehri derneklerinin bağlı oldukları federasyonlar yoluyla yapılmasını beraberinde getirmiştir. Federasyonlar en az beş derneğin bir araya gelmesiyle kurulmaktadır (Dernekler Kanunu No:5253, Tarih 04.11.2004 ve Dernekler Yönetmeliği, Resmi Gazete Tarihi: 31.03.2005, Sayı 25772). Her il kapsamında; il, ilçe ve köy derneklerini bir araya getiren federasyonlar il tanıtımı ve faaliyetlerin yürütülmesinde etkin bir merkez olabilmektedir. Aktif bazı federasyonlar, sayısı 100'ü aşan hemşehri derneğini on binlerce üyesiyle bünyesinde barındırabilmektedir. Aynı zamanda iletişim kanallarının çeşitliliği ve sivil toplum örgütü olarak temsil etkisi, etkinlik, organizasyon düzenleme ve katılımın sağlaması konusunda etkin rol almalarını sağlamaktadır. Bünyesindeki derneklerin katılımıyla oluşan federasyon yönetimi, köy ölçeğindeki hemşehri derneğini tanıma ve afet konusundaki görüşlerini almada daha kolay ulaşılabilir bir üst ağ olarak görülebilmektedir.

İstanbul'da bulunan hemşehri derneklerinin bağlı olduğu federasyon bilgilerine, T.C. İçişleri Bakanlığı, Dernekler Dairesi başkanlığı, İstanbul Valiliği, İ Dernekler Müdürlüğü'ne başvuru yolu ile (13.07.2017 tarih /E.55080 Sayılı izni) ulaşılmıştır. Bu doğrultuda hemşehri derneklerinin bağlı olduğu federasyonlarla iletişim kurulmuş ve görüşmeyi kabul eden toplam altı hemşehri dernekleri federasyon yönetim kurulu başkanları ile yarı yapılandırımış görüşme tekniği ile yüz yüze görüşme gerçekleştirilmiştir.

Nitel veri toplama yöntemi kullanılan araştırmada yarı-yapılandırılmış görüşme tekniğinden yararlanılmıştır. Konuyla ilgili önceden hazırlanan belli konu başlıkları ve sorularla görüşmeler gerçekleştirilmiştir. Görüşmeler; federasyonun amacı, faaliyetleri, faaliyet sıklığı, federasyon binasının fiziki yapısını içeren sorularla başlamıştır. Devamında ise katıımcılara federasyon bünyesinde gerçekleştirilen afet eğitimleri sorulmuş, temel afet bilinci eğitimi hakkındaki fikirleri alınmıştır. Görüşmeler not olarak yazılı kaydedilmiştir. Katılımcıların belirlenmesinde kartopu örneklem tekniği kullanılmıştır. Bu teknik ile aktif olan federasyon temsilcilerine ulaşıldığında, bu temsilcilerin yönlendirmesi ile başka aktif federasyonlara da ulaşma imkânı olmuştur.

Türkiye genelinde İçişleri Bakanlığı, Dernekler Dairesi Başkanlığı'na bağlı olarak, 21 farklı faaliyet alanında olacak şekilde toplamda yaklaşık 11 milyon üyesiyle 111 bine yakın faal dernek bulunmaktadır (DERBIS, 2017). Genel toplamdaki dernek üyelerinin üç milyona yaklaşan kısmı ise İstanbul'dadır. Hemşehri dernekleri Türkiye genelinde dernek sayısı bakımından ilk sırada olan mesleki ve dayanışma dernekleri altında tanımlanmıştır. Spor ve sporla ilgili dernekler ise ikinci gruptadır. Yıllar içinde kentleşme oranın artmasıyla hemşehri derneklerinde sayıca düşüş yaşansa da (Acar, 2010), yine de bu dernekler diğerlerine göre çoğunluktadır. Ayrıca bu derneklerin siyasal, sosyal ve kültürel alanda da etkin oldukları, yerel yönetimlerde söz sahibi oldukları görülmektedir (Akça, 2012; Özdemir, 2013). Dernekler Dairesi Başkanlığı 2016 istatistiklerine göre Türkiye genelinde toplam sayısı 16bine (15441 dernek) yaklaşan hemşehri derneklerinin yarıdan fazlası (8201dernek) Marmara bölgesinde bulunmaktadır. Bunların büyük bir bölümü (6204 dernek) ise İstanbul ve çevresindedir. Bu, aynı zamanda en yoğun göç olgusunun yaşandığı bölge olmasıyla paralel bir durum olarak görülebilir.

Hemşehri derneklerinin afet bilinci geliştirmede kapasitelerinin belirlenmesine yönelik olarak; mevcut fiziksel altyapı, yönetimsel yapılanma ve esneklik, karar alma tutumları, afetle ilgili mevcut ve planlanan çalışmalar, afet konusundaki bilgi birikimi ve bu yönde hedeflenen çalışmaların varlığı araştırımıştır. Görüşme soruları hemşehri derneklerinin bağlı olduğu federasyona ilişkin genel özellikler ve afet kapsamında ayrıntılı konuları kapsayan iki bölümden oluşmaktadır. İlk bölümdeki genel özellikler kapsamında; mevcut altyapı olanakları, faaliyet alanları, gerçekleştirdikleri ve planladıkları etkinlikler, ulaştıkları üye sayısı 
benzeri bilgilerin toplanması hedeflenmiştir. Afetle ilgili ikinci bölümünde ise temel afet bilinci tanımı görüşmeciye açıklanarak, afet bilgisi, afet kapsamında üyelerden gelen talepler, afet bilinci geliştirme yönünde eğitimin federasyon bünyesinde dernek üyelerine verilmesinin uygunluğu konusundaki görüşleri alınmıştır.

\section{İstanbul Yozgatlılar Federasyonu}

İstanbul Yozgatılılar Federasyonu faaliyetini İstanbul Fatih'te, üst katları öğrenci yurdu, giriş ve birinci katları federasyon merkezi olarak kullanılan yeni yapılmış (2017) yedi katlı bir binada sürdürmektedir. 2004'de kurulan Yozgatlılar Federasyonuna 25bin üye ile 60 dernek bağlıdır. Federasyon merkezi haftanın bütün günleri açık ve etkinlikler için merkez binadaki konferans salonu kullanılmaktadır. Federasyonda bağlı derneklerle iletişimde telefon, internet, sosyal medya kullanılmaktadır. Bir önceki yıl gerçekleşen faaliyetler kapsamında daha çok dayanışma yemekleri, piknik, konser ve anma etkinlikleri düzenlenmiştir. Eğitim amaçlı etkinlikler ise gençlik kariyer günleri, işadamı gençlik buluşması gibi gençlerin geleceğine destek içerikli eğitim amaçlı etkinlikleri bulunmaktadır. Gelecekteki hedeflerinde ise proje yazımı ile ilgili eğitim olup, Yozgat iline turistik gezi ve yangın tatbikatı konusunda etkinlikleri planladıklarını belirtmişlerdir. Federasyonun düzenlediği etkinliklere katılım sayısı 100'ün üzerindedir.

\section{Artvin Dernekler Federasyonu}

Artvin Federasyonu faaliyetini İstanbul Ataşehir'de sürdürmektedir. 2013'de kurulan Artvin Dernekler Federasyonuna 3800 üye ile 13 dernek bağlıdır. Etkinlikler için kapalı salon kullanılmaktadır. Federasyonda bağlı derneklerle iletişimde telefon, internet, sosyal medya kullanılmaktadır. Yılda ortalama beş farklı faaliyetin gerçekleştiği federasyonda etkinlikler eğitim ve tanıtım ağırlıklıdır. Eğitim faaliyetlerinden biri sertifikalı deprem için ilk 72 saat kurtarma eğitimi olmuştur.

\section{Gümüşhane Dernekler Federasyonu}

Gümüşhane Dernekler Federasyonu faaliyetini İstanbul Mecidiyeköy merkez olmak üzere üç bölge başkanlığı ile faaliyettedir. 2007'de kurulan Gümüşhane Dernekler Federasyonuna 10bin üzeri üye ile 17 il, 123 köy, ilçe belde derneği bağlıdır. Federasyon bölge başkanlıklarında toplantı ve etkinlik amaçlı bir araya gelinmektedir. Federasyonda bağlı derneklerle iletişimde telefon, internet, sosyal medya kullanılmaktadır. Bir önceki yıl gerçekleşen faaliyetler kapsamında daha çok piknik, spor faaliyetleri, eğlence, eğitim temelli etkinlikler düzenlenmiştir. Eğitim amaçlı etkinlikler ise burs ve eğitim bilgilendirmesini içeren etkinlikleri bulunmaktadır. Gelecekteki hedeflerinde ise "ilimi ileri seviyede tanıtmak" amaçlı etkinlikler planladıklarını belirtmişlerdir. Federasyon tarafından düzenlenen yıllık etkinlik ortalaması 10-20 arasındadır.

\section{Taşova Dernekler Federasyonu}

Taşova Dernekler Federasyonu faaliyetini İstanbul Bağcılar'da, sürdürmektedir. 2013'de kurulan Taşova Dernekler Federasyonuna yaklaşık 4bin üye ile 22 dernek bağlıdır. Etkinlikler için belediye ve üye dernek salonları kullanılmaktadır. Federasyonda bağlı derneklerle iletişim ve duyurular için cep telefonu, internet sitesi, sosyal medya kullanılmaktadır. Bir önceki yıl gerçekleşen faaliyetler kapsamında daha çok dayanışma yemekleri, piknik, spor amaçlı turnuva benzeri etkinlikler düzenlenmiştir. Federasyon tarafından burs için sandık faaliyeti bulunmaktadır. Gelecekteki hedeflerinde ise hentbol takımı desteği için salon toplantıları planladıklarını belirtmişlerdir.

\section{Kâhta Dernekler Federasyonu}

Kâhta Dernekler Federasyonu faaliyetini İstanbul Gaziosmanpaşa'da, 1990 yılında inşa edilmiş beş katı iş merkezinin 5.katında sürdürmektedir. Federasyon 2013'de kurulmuş, 12 
dernek ve 4 bin üyesi bulunmaktadır. Federasyon merkezi hafta içi açık ve toplantılar için üye dernek merkezleri kullanılmaktadır. Federasyonda bağlı derneklerle iletişimde telefonu ve kısa mesaj (sms) kullanılmaktadır. Federasyonda bir önceki yıl etkinlik ortalama 10-20 arasındadır. Bir önceki yıl gerçekleşen faaliyetler kapsamında daha çok dayanışma, iftar yemekleri, piknik, spor müsabaka etkinlikleri düzenlenmiştir. Gelecekte proje ve fon desteği alımı ile ilgili eğitim alma hedefleri olup, yöre tanıtım günleri, piknik, futbol turnuvası etkinlikleri planladıklarını belirtmişlerdir. Federasyonun düzenlediği etkinliklere katıım sayısı 100'ün üzerindedir.

\section{Çorum Hitit Dernekleri İstanbul Federasyonu}

Çorum Hitit Dernekleri İstanbul Federasyonu faaliyetini Avcılar'da sürdürmektedir. 2013'de kurulan Federasyona 3bin üye ile 12 dernek bağlıdır. Federasyonda bağlı derneklerle iletişimde telefon kullanılmaktadır. Bir önceki yıl gerçekleşen faaliyetler ortalama beş olup, daha çok dayanışma yemekleri, piknik, burs verme etkinlikleri düzenlenmiştir. Gelecekteki hedeflerinde ise proje döngüsü, kadın ve gençlere yönelik eğitimler, farkındalık ve eğitici eğitimleri olup, konser, eğitim burs faaliyetleri kapsamında etkinlikler planladıklarını belirtmişlerdir. Federasyonun düzenlediği etkinliklere katıım sayısı 100'ün üzerindedir.

\section{BULGULAR}

Hemşehri dernekleri Türkiye'nin farklı şehirlerini temsilen kültürel zenginlik içeren yapıdadır. Her ne kadar köy dernekleri kapsamında değerlendirilse de kent yaşamının bir parçası olan toplulukların zamanla kent yaşamı bağlamında yeni konular geliştirdiği düşünülmektedir. İstanbul'da sayıları altı bini aşan hemşehri dernekleri 135 federasyon altında toplanmıştır. Dernek sayısı ve İstanbul'daki dağılımı, görüşmenin binleri bulan hemşeri derneklerinin bağlı oldukları federasyonlarla yapılmasında etkili olmuştur.

Hemşehri dernekleri geldikleri yöre kültürü bağlamında kentlerde ağırlıklı olarak sosyal dayanışma amaçlı varlığını sürdürmektedir. Yapılan görüşmelerde gençlere eğitim desteği sağlama, sportif faaliyetler ve yetenekli gençlerin teşviki yönünde çalışmaların yapıldığı görülmüştür. Dayanışma yemeği ve piknik etkinlikleri çokça yer alan etkinliklerdendir. Görüşülen federasyonlara göre gelecekte planlanan eğitimlerde proje yazma konusu öne çıkmaktadır.

Afet konusunun önemli olduğu belirtilmekle birlikte, gerçekleşen veya planlanan etkinlikeğitim amaçlı faaliyetler içinde çok az yer almaktadır. Afet durumunda ne yapılacağına ve AFAD Kurumu konusundaki bilgilenmenin çoğunlukla basından ulaşılıyor olması, basın/medyanın afet konusunda önemli bir bilgilenme aracı olduğunu göstermektedir.

Afet eğitiminin genel olarak önemli bulduklarını, üyelerin de istekli olacaklarını belirtmekle birlikte bu konuda herhangi bir talep olmadığı belirtilmektedir. Afet bilinci geliştirme eğitiminde eğitici eğitimleri kanalıyla toplumun daha geniş kesimine yayılma kolaylaşmaktadır. Eğitici eğitimi almış dernek veya dernekleri çatısı altında toplamış olan federasyon yönetiminden birisinin üyelere eğitim vermesi konusunda ise çok belirgin bir eğilim olduğunu söylemek mümkün değildir.

Görüşülen kişilerden yalnızca biri afet eğitimi aldığını, bu nedenle afetle karşılaştığında neler yapması gerektiğini bildiğini belirtmiş, diğer kişiler herhangi bir afet durumunda yapılması gerekenlerin neler olduğu konusunda orta düzeyde bilgisi olduğunu veya bilgisi olmadığını belirtmişlerdir. Görüşülen federasyon temsilcilerine afet konusunda daha önce herhangi bir eğitimin federasyon bünyesinde alınıp alınmadığı sorulmuştur. Yalnızca bir federasyon temsilcisi daha önce federasyon bünyesinde üyelerle birlikte afet eğitimi aldıklarını belirtmiştir. Diğer federasyonlarda ise afet eğitiminin yapılmadığı ve böyle bir talebin 
gelmediği anlaşılmıştır. Görüşülen bir federasyon temsilcisi hariç diğerleri afet eğitimi almak istenildiği takdirde nereye başvuracaklarını bildiklerini belirtmişlerdir.

Görüşmeler sırasında Afet ve Acil Durum Yönetim Başkanlığı AFAD hakkında kısa bir bilgi verilmiş, bu kurumu tanıyıp tanımadıkları öğrenilmek istenmiştir. Görüşülen temsilcilerin hepsi kurumu bildiklerini bir düzeyde bilgi sahibi olduklarını belirtmişlerdir. AFAD hakkında bilginin basından edinildiği anlaşılmıştır.

Federasyon temsilcilerine temel afet bilinci eğitimi hakkında kısa bir bilgilendirme yapılarak, bu eğitimi federasyon bünyesinde gerçekleştirme konusunda fikirleri alınmıştır. Görüşülen temsilcilerden beşi temel afet bilinci eğitimini çok gerekli bulduklarını belirtirken, yalnızca biri gerekli bulmuştur. Görüşülen kişilerin tümü üyelerin bu eğitimi almaya istekli olacaklarını düşündüklerini belirtmişlerdir. Son olarak temel afet bilinci eğitimini federasyon içinden birinin mi yoksa dışarıdan bir eğitimcinin mi vermesi gerektiği konusunda fikirleri sorulmuştur. Bu noktada katılımcıların verdikleri cevaplar farklılık göstermiştir. İki kişi eğitimin federasyon dışından biri tarafından verilmesinin daha uygun olacağını düşünürken, diğerleri federasyon içinden bir üyenin vermesinin daha uygun olacağını belirtmiştir.

\section{SONUÇ}

Afet için dayanışma, özellikle afet sonrası hayatın yeniden normale dönmesi kapsamında önem taşımaktadır. Bu yönde yapılan çalışmalarda sosyal sermayesi güçlü toplumların afet sonrası dayanışmada daha avantajı olduğunu göstermektedir. Hemşehri dernekleri yaygın sosyal ağı ile büyük kentlerde dayanışma amaçlı önemli sivil toplum kuruluşlarıdır. Farklı birçok iletişim kanalları ile üyelerine kolaylıkla ulaşabilmekte, birçok etkinliklerle bir araya gelebilmektedir. Piknik, yemek, sportif faaliyetlerde bir araya gelen üyeler, gençlerin eğitimine destek amaçlı burs faaliyetinde de bulunmaktadır. Daha çok dayanışma amaçlı kurulmuş hemşehri dernekleri sosyal ağının bu yönde de kullanılabilirliği olası görünmekle birlikte afet konusunda ön bilgilendirmenin yapılmasına intiyaç görünmektedir. Bu süreçte afet bilinç geliştirme yönünde eğitim kolaylıkla entegre edilebilir görünmektedir. Bu türden eğitimlerin kim tarafından verilebileceği ise ön çalışmalarla netleşebileceği düşünülmektedir. Dernek veya federasyon yöneticilerinin alacağı eğitici eğitimleri sonrasında, kendi üyelerine kolaylıkla aktarabileceği öngörülmektedir. Eğitimin verileceği yerin seçimi ise derneklerin merkezlerinde olması, üyelerin erişimi açısından daha uygun görünmektedir.

Görüşülen federasyon temsilcileri temel afet eğitiminin gerekliliğine inanan, eğitim talep edildiğinde, organize etmek için istekli olacak yetkililerdir. Ayrıca eğitim düzenlendiği takdirde üyelerin ilgisinin yüksek olacağı öngörülmektedir. İçlerinden yalnızca bir federasyon temsilcisi ise bu eğitimi üyelerle birlikte aldığını belirtmiş, konuya federasyon olarak önem verdiklerini dile getirmiştir. Üyeler; hali hazırda sosyal bağları güçlü olan gruplar olduğundan, eğitimin duyurulması ve yaygınlaştırılmasının kolay olacağı öngörülmektedir. Afet sonrası iyileşme (normale dönüş,) süresince sosyal sermayesi güçlü olan toplulukların daha hızlı sonuçlar aldığı bilinmektedir. Afet eğitimi alma konusunda istekli olan hemşehri topluluklarının bu eğitimi aldıkları takdirde, afet sonrası toparlanma sürecinde daha güçlü olacakları öngörülmektedir. Her ne kadar görüşülen federasyon temsilcileri bu konuda istekli olsa da, görüşme yapılamayan, ulaşılamayan federasyon temsilcileri de sayıca fazladır. Belirli federasyonların temsilcilerinden cevap alınamamış, kullanılan iletişim yollarının aktif olmadığı anlaşılmıştır. Ancak bu durum, federasyonların yönetim yapısıyla ilişkilendirilmektedir. Yardımlaşma, eğitim ve kültür faaliyetleri ile sosyal etkinlik amacıyla bir araya gelen federasyonların, genellikle yılda birkaç kez, bağlı olan derneklerle etkinlik gerçekleştirdiği ve bu faaliyetler dışında aktif olmadığı anlaşılmıştır. 
Federasyonlar, bağlı olan derneklerle birlikte önemli bir sosyal ağ oluşturmaktadır. Senede birkaç etkinlik yapılsa da dernek üyelerini bir araya getirip büyük çapta etkinlikler yapma gücünün olduğu anlaşılmıştır. Var olan sosyal sermayeyi kullanmak, temel afet eğitimi konusunda istekli olduğu anlaşılan toplulukları afet eğitimine yönlendirmek için hemşehri derneklerinin önemli olduğu düşünülmektedir. Bu çalışma temel afet eğitiminde var olan sosyal dayanışma ağlarından yararlanılmasının gerekliliğini ortaya koymuştur. Afet eğitiminin federasyon bünyesinden birinin vermesinin, eğitime katılımı arttıracağı sonucuna ulaşılsa da, bu konuda diğer etkin yolların ne olacağı gelecek çalışmalar için bir soru olacaktır.

\section{KAYNAKLAR}

Acar, Ş. (2010). "Sivil Toplum Kurumu Olarak Türkiye'de Derneklerin Profili”, Yüksek Lisans Tezi (Yayınlanmamış), Sakarya Üniversitesi, Sosyal Bilimler Enstitüsü, Sakarya.

AFAD. (2013). UDSEP Ulusal Deprem Stratejisi ve Eylem Planı 2012-2023. Ankara: T.C. Başbakanlık Afet ve Acil Durum Yönetimi Başkanlığı.

Akça, E. (2012). "Büyükşehir Belediyelerinde, Hemşehri Derneklerinin Yerel Siyaset ve Kent Yönetimi Üzerindeki Etkileri”, Yüksek Lisans Tezi (Yayınlanmamış), Bahçeşehir Üniversitesi, Fen Bilimleri Enstitüsü, İstanbul.

Arama Kurtarma Derneği, AKUT. (2015). "Afet ve Deprem Bilinçlendirme Semineri". https://www.akut.org.tr/2015-yili-seminer-verileri Son Erişim Tarihi 10 Temmuz 2017

Altay, N. (2009). “İzmir'de Hemşehri Dayanışmasının Kent Kültürü Üzerindeki Etkileri”, Doktora Tezi (Yayınlanmamış), Dokuz Eylül Üniversitesi, Eğitim Bilimleri Enstitüsü, İzmir.

Ayça Kurtoğlu, «Mekânsal Bir Olgu Olarak Hemşehrilik ve Bir Hemşehrilik Mekanı Olarak Dernekler», European Journal of Turkish Studies [Online], 2 | 2005, http://journals.openedition.org/ejts/375

Afet ve Acil Durum Yönetimi Başkanlığı, AFAD (2017). "Afete Hazır Türkiye Bilinçlendirme ve Eğitim Projesi, 2012-2017", TC İçişleri Bakanlığı, Afet ve Acil Durum Yönetimi Başkanlığı, https://www.afad.gov.tr/tr/2501/Afete-Hazir-Turkiye-Bilinclendirme-ve-Egitim-Projesi Son Erişim tarihi 01 Temmuz 2017

Avcilar Belediyesi AB. (2018). Avcılar Belediyesi Afet Gönüllüleri projesi ABAG http://www.avcilar.bel.tr/lcerikler/Hizmetlerimiz/Abak

Dernekler Bilgi Sistemi İstatistikleri, DERBİS.(2017). "Dernekler Bilgi Sistemi İstatistikleri" T.C. İçişleri Bakanlığı, Dernekler Dairesi Başkanlığı, https://www.dernekler.gov.tr/tr/Derneklslemleri/istatistikler.aspx Son Erişim tarihi 30 Haziran 2017

Gürbüz D., Yücel G. (2017). "Role of NGOs in Disaster Awareness, Fellow Countryman (Hemşehri) Associations", Poster Sunum, World Bosai Forum World Bosai Forum/ IDRC International Disaster Risk Conference, 25-28 November, 2017, Tohoku University, Sendai, Japan

İstanbul Büyükşehir Belediyesi, İBB. (2002). "Türkiye Cumhuriyeti İstanbul ili Sismik Mikro Bölgeleme Dâhili Afet Önleme/ Azaltma Temel Planı Çalışması”, Son Rapor, Cilt 5, 2002. http://www.ibb.gov.tr/tr-TR/SubSites/DepremSite/Publishinglmages/JICA-TUR.pdf Son Erişim Tarihi 01 Temmuz 2017. 
İstanbul Büyükşehir Belediyesi, İBB.(2003). "IDMP, İstanbul İçin Deprem Master Planı, 2003". http://www.ibb.gov.tr/tr-TR/SubSites/DepremSite/Documents/\%C4\%B0DMP_TUR.pdf Son Erişim Tarihi 01 Temmuz 2017.

International Federation of Red Cross and Red Crescent Societies, IFRC, (2011). "Public awareness and public education for disaster risk reduction: a guide". Geneva, IFRCRCS, http://www.ifrc.org/Global/Publications/disasters/reducing_risks/302200-Public-awareness-

DDR-guide-EN.pdf Son Erişim tarihi 20 Haziran 2017

İstanbul Valiliği., İstanbul Proje Koordinasyon Birimi, IPKB. (2017). "Toplumun Afetler Hakkında Bilinçlendirilmesi ve Eğitimi” http://www.ipkb.gov.tr/tr/bilesen/kategori/toplumunafetler-hakkinda-bilinclendirilmesi-ve-egitimi Son Erişim Tarihi 10 Temmuz 2017

Jeanne Hersant et Alexandre Toumarkine, «Hometown organisations in Turkey: an overview»,European Journal of Turkish Studies [En ligne], 2 | 2005

KRDAE. (2017). "AHEB ABCD - Temel Afet Bilinci Eğitim Programı". Boğaziçi Üniversitesi, Kandilli Rasathanesi Deprem Araştırma Enstitüsü, KRDAE, http://www.koeri.boun.edu.tr/aheb/abcd.asp Son erişim tarihi 10 Haziran 2017

Koçak Y. ve Terzi, E. (2014). Hemşehri Dernekleri, Hemşehrilik Bilinci ve Kentlileşme İlişkisi Üzerine Bir Araştırma: İstanbul/Sultangazi'deki Karslı Hemşehri Dernekleri. Selçuk Üniversitesi Sosyal Bilimler Enstitüsü Dergisi Sayı: 32, ss. 137-150.

Maskrey, A. (1989). Disaster Mitigation—A community based approach, London: Oxfam.

Milli Eğitim Bakanlığı, MEB.(2011). Can ve Mal Güvenliği Afet Bilinci Eğitimi Modüler Programı. https://hbogm.meb.gov.tr/ Son Erişim Tarihi 05 Mayıs 2017

Nakagawa, Y., Shaw, R. (2004). Social Capital:A Missing Link to Disaster Recovery, International Journal of Mass Emergencies and Disasters , Vol. 22, No. 1, pp. 5-34.

Özdemir, G. (2013). Tampon Mekanizmadan Siyasal Aktörlüğe Hemşehri Dernekleri. Turkish Studies - International Periodical For The Languages, Literature and History of Turkish or Turkic Volume 8/5 Spring 2013, p. 577-593.

Shaw, R. (2012). "Corporate Community Interface: New Approaches In Disaster Risk Reduction" Community-Based Disaster Risk Reduction Community, Environment and Disaster Risk Management, Emerald Group Publishing Limited. Volume 10, 67-87

The United Nations Office for Disaster Risk Reduction. 2015. "Sendai Framework for Disaster Risk Reduction 2015-2030". https://www.unisdr.org/files/43291_sendaiframeworkfordrren.pdf Son erişim tarihi 28 Haziran 2017

URL-1: Anadolu Ajansı, 10 Kasım 2018 tarihli, "11 milyon kişiye 'afete hazırlık' eğitimi" haberi: https://www.aa.com.tr/tr/turkiye/11-milyon-kisiye-afete-hazirlik-egitimi/1307557

URL-2: Kadıköy Belediyesi, 11 Ekim 2018 tarihli haber: http://www.kadikoy.bel.tr/Haberler/turkiyenin-ilk-afet-egitim-parki-kadikoyde-acildi 
URL-3: Esenler Belediyesi Arama Kurtarma Ekibi- ESKAT, Afet Bilinci Eğitimi: http://eskat.esenler.bel.tr/egitimler/afetbilinci.html

URL-4: Kartal Belediyesi- AKUT Vakfı Toplum Afet Bilinçlendirme Merkezi, 1 Mart 2019 tarihli haber: https://www.kartal.bel.tr/tr/haberler/Habergoster.aspx?id=17787 